\title{
Audyt krajobrazowy jako „Nowy instrument ochrony krajobrazu”
}

\author{
Jakub Wiśniewski \\ Uniwersytet Gdański, Wydziat Oceanografii i Geografii, Instytut Geografii \\ E-mail:jakub_wisnie@wp.pl \\ tutor: dr Katarzyna Jereczek-Korzeniewska \\ Uniwersytet Gdański, Wydziat Oceanografii i Geografii, Instytut Geografii, \\ Zakład Hydrologii
}

Stowa kluczowe: ochrona przyrody, krajobraz, ustawa, audyt

Wprowadzenie - historia ochrony przyrody w Polsce przed przystąpieniem do Unii Europejskiej

Polska ma bogate i głęboko zakorzenione tradycje związane z ochroną przyrody, które sięgają czasów panowania Bolesława Chrobrego. Okresem, w którym rozpoczęto działania na większą skalę, był natomiast XX wiek. W tym okresie, a konkretnie w 1919 roku powstała Państwowa Tymczasowa Komisja Ochrony Przyrody przy Ministerstwie Wyznań Religijnych i Oświecenia Publicznego. Przekształcona została następnie w Państwową Radę Ochrony Przyrody siedem lat później. Z inicjatywy wspomnianej instytucji utworzono w 1928 roku Ligę Ochrony Przyrody. Efektem działań nowo powstałych organów było utworzenie 39 rezerwatów przyrody, które powołano w dwudziestoleciu międzywojennym. W tym samym okresie powstała pierwsza ustawa, która regulowała ochronę przyrody w naszym kraju, a mianowicie ustawa o ochronie przyrody z 1934 roku. Jeszcze przed wybuchem II wojny światowej utworzono także pierwsze parki narodowe: białowieski, pieniński, wielkopolski, babiogórski i tatrzański [1].

W okresie PRL-u temat ochrony przyrody zaczął docierać do coraz większych rzeszy zwykłych obywateli. Duży swój udział miały w tym Lasy Państwowe. W tym czasie powołano wiele $z$ istniejących dziś parków narodowych, a także ponad 100 parków krajobrazowych. Znacznie zwiększono liczbę rezerwatów przyrody. Całokształt ochrony środowiska naturalnego, w tym oczywiście krajobrazu w Polsce, miał jednak wkrótce przybrać zupełnie nową formę. Tym momentem w historii ochrony przyrody w Polsce był dzień dołączenia Polski do Unii Europejskiej w 2004 r. 
Audyt krajobrazowy - pozycja w polskim ustawodawstwie

Jedną z konsekwencji tego wydarzenia było ratyfikowanie przez Polskę Europejskiej Konwencji Krajobrazowej (EKK), która stała się od tego momentu dokumentem bazowym dla przyszłych działań na rzecz ochrony krajobrazu. Art. 6 uchwalonego we Francji dokumentu określa także specjalne środki, które każda ze stron jest zobowiązana podjąć w celu zrealizowania wymagań Konwencji.

W kolejnych latach polski rząd wprowadzał zmiany w przepisach dotyczących ochrony przyrody, aby te wymagania spełnić. Zwieńczeniem prac była tzw. „Ustawa Krajobrazowa" z 2015 r (Dz.U. 2015 poz. 774). Na jej właśnie podstawie mają być sporządzane audyty krajobrazowe.

\section{„Nowy instrument ochrony krajo-} brazu"

W tym właśnie momencie warto przejść do meritum, a więc do tytułowego "nowego instrumentu ochrony krajobrazu". Audyt krajobrazowy to zupełnie nowy koncept w polskim systemie prawnym. Zakres jego opracowania miał objąć obszar całego województwa [2]. W celu jego odpowiedniej implementacji potrzebny był dokument, który w jasny i klarowny sposób określiłby wymagania jakie należy spełnić sporządzając audyt oraz opisać następujące po sobie etapy jego tworzenia.

\section{Sporządzanie audytu}

W tym celu dnia 11 stycznia 2019 r. zostało uchwalone Rozporządzenie Rady Ministrów w sprawie sporządzania audytów krajobrazowych. Zostało spisane na podstawie art. 38a ust. 6 ustawy z dnia 27 marca 2003 r. o planowaniu i zagospodarowaniu przestrzennym (Dz. U. z 2018 r. poz. 1945 oraz z 2019 r. poz. 60). Zgodnie z Rozporządzeniem procedura tworzenia dokumentu audytu następuje w konkretnych, powiązanych ze sobą etapach. Pierwszem krokiem jest identyfikacja istniejących na obszarze danego województwa krajobrazów, którą dokonuje się zgodnie z załączoną klasyfikacją. Następnie należy scharakteryzować każdy z nich, aby w dalszej kolejności wyznaczyć tzw. krajobrazowy priorytetowe. W kolejnych dwóch etapach następuje wskazanie zagrożeń dla możliwości zachowania najbardziej cennych walorów każdego z krajobrazów oraz sformułowanie rekomendacji i wniosków w celu lepszego i skuteczniejszego kształtowania i ochrony krajobrazów. Ostatnim krokiem jest określenie lokalnych form architektonicznych zabudowy dla krajobrazów priorytetowych.

Struktura projektu audytu krajobrazowego

Wykonany audyt krajobrazowy składa się z dwóch części: opisowej oraz graficznej, a także załączonej do projektu dokumentacji. Część opisowa zawiera przede wszystkim ogólne informacje na temat województwa, dla którego sporządzano audyt, wspomnianą wcześniej charakterystyką poszczególnych krajobrazów na obszarze opracowania oraz wykaz krajobrazów priorytetowych. Część graficzna natomiast obejmuje wizualizacje w postaci map, na których przedstawiane są zidentyfikowane krajobrazy, lokalizacja krajobrazów priorytetowych i mapa obszarów lub obiektów o znaczących walorach krajobrazowych. Mapy te sporządza się w skalach 1:50 000 oraz 1:2000.

W celu precyzyjnego wykonania identyfikacji krajobrazów priorytetowych oraz odpowiedniej analizy ich struktury 
w Rozporządzeniu zamieszczono szereg załączników, które zawierają szczegółowe zalecenia dla poszczególnych etapów pracy nad audytem. Mają one na celu wspomóc samorządy województw w naszym kraju w odpowiednim wykonaniu kolejnych kroków w procedurze sporządzania audytu krajobrazowego. Pierwsze z nich opisują cały proces identyfikacji krajobrazów na terenie województwa (w tym krajobrazów priorytetowych), klasyfikację krajobrazów jaką należy się kierować przy tworzeniu audytu, metodykę pracy, sposób oceny zidentyfikowanych krajobrazów oraz bardzo istotne w audycie krajobrazowym Karty Charakterystyki Krajobrazu [3].

Warto się pochylić nad tymi kartami, ponieważ są one swego rodzaju kręgosłupem wykonywanego audytu. Wypełnia się je dla każdego zidentyfikowanego krajobrazu w obszarze opracowania i określa właściwe dla niego cechy oraz wskaźniki. Aby właściwie takie elementy wyznaczyć opisać powstały tabele tychże cech krajobrazowych razem z odpowiadającymi im wskaźnikami. Obowiązuje je także kilka podziałów. Pierwszym z nich jest rozdzielenie na dwie kategorie: przyrodnicze oraz kulturowe. Drugim działaniem jest wyznaczenie osobno cech charakterystycznych typologicznie oraz cech unikatowych, aby jeszcze lepiej i dokładniej podkreślić znaczenie najważniejszych dla danego krajobrazu elementów.

W końcowej części dokumentu umieszczono w załącznikach pomocniczych między innymi klasyfikację zagrożeń, jakie mogą wpłynąć na funkcjonowanie i kształt danego krajobrazu oraz wytyczne w zakresie formułowania rekomendacji i wniosków dotyczących kształtowania i ochrony krajobrazów. Te dwa elementy stanowią swego rodzaju podsumowanie całego dokumentu i mają na celu zapewnienie odpowiedniej ochrony wyznaczonym krajobrazom na obszarze badanego województwa.
Zakładane efekty wykonania audytu

Proces sporządzania audytu krajobrazowego jest niezwykle złożony i szczegółowy. Jego wykonawcy muszą dokładnie przestudiować omówiony wyżej dokument, aby należycie zidentyfikować i scharakteryzować każdy z krajobrazów jaki można wydzielić na obszarze województwa. Jest to także proces czasochłonny i kosztowny, ponieważ przeprowadzone badania muszą zostać poparte odpowiednimi wizualizacjami oraz dokumentacją projektową. W jaki sposób zatem audyt wpływa na funkcjonowanie ochrony krajobrazu danego województwa? Jaki efekt wywołuje uchwalenie tego dokumentu?

Na pewno uzyskana wiedza na temat walorów krajobrazowych na obszarze opracowania ma mieć trwały efekt na podejściu mieszkańców do ochrony lokalnego środowiska. Należy jednak regularnie tę wiedzę odświeżać. W związku z tym audyt krajobrazowy sporządza się co 20 lat. Po wykonaniu pierwszego audytu każdy kolejny ma na celu ponowne wyznaczenie krajobrazów priorytetowych, a następnie dokonanie oceny zmian i ewentualnej aktualizacji danych. Co ważne, taki dokument nie stanowi co prawda aktu prawa lokalnego, jednakże zawarte w nim wnioski oraz rekomendacje posłużyć mogą planistom, którzy dbają o ład przestrzenny w danym województwie.

\section{Podsumowanie i wnioski}

Nie ulega już wątpliwości, że audyt krajobrazowy jest dokumentem bardzo szczegółowym i zawierającym w swoich zapisach rzetelnie zebrane informacje na temat krajobrazów danego województwa. Realizowany jest obecnie w wielu województwach naszego kraju, między innymi w województwie pomorskim, zachodniopomorskim oraz dolnośląskim. Sam osobiście $w$ ramach studiów 


\section{Tutoring Gedanensis}

I stopnia stworzyłem pracę dyplomową wykorzystując właśnie metodykę audytu krajobrazowego, jednak w dużo mniejszej skali i dla mniejszej jednostki administracyjnej, którą była gmina Łubianka (Ryc. 1). Zalecane w Rozporządzeniu metody inwentaryzacji, a także analizy obiektów przyrodniczych oraz kulturowych pomogły w ocenie zróżnicowania krajobrazu na obszarze opracowania (Ryc. 2). Pomogły w tym szczegółowe tabele zawarte w podanym wyżej dokumencie, w których każda z cech krajobrazowych została dokładnie opisana i przyporządkowana do odpowiedniej kategorii (np. przyrodnicza lub kulturowa). Dzięki tym podpowiedziom możliwe było również określenie, które elementy lokalnego krajobrazu są najbardziej unikatowe. Moja analiza przeprowadzona została na bazie kilkunastu obrębów ewidencyjnych, które stały się polami odniesienia, tak aby można było porównać wyniki badań w różnych częściach gminy Łubianka.

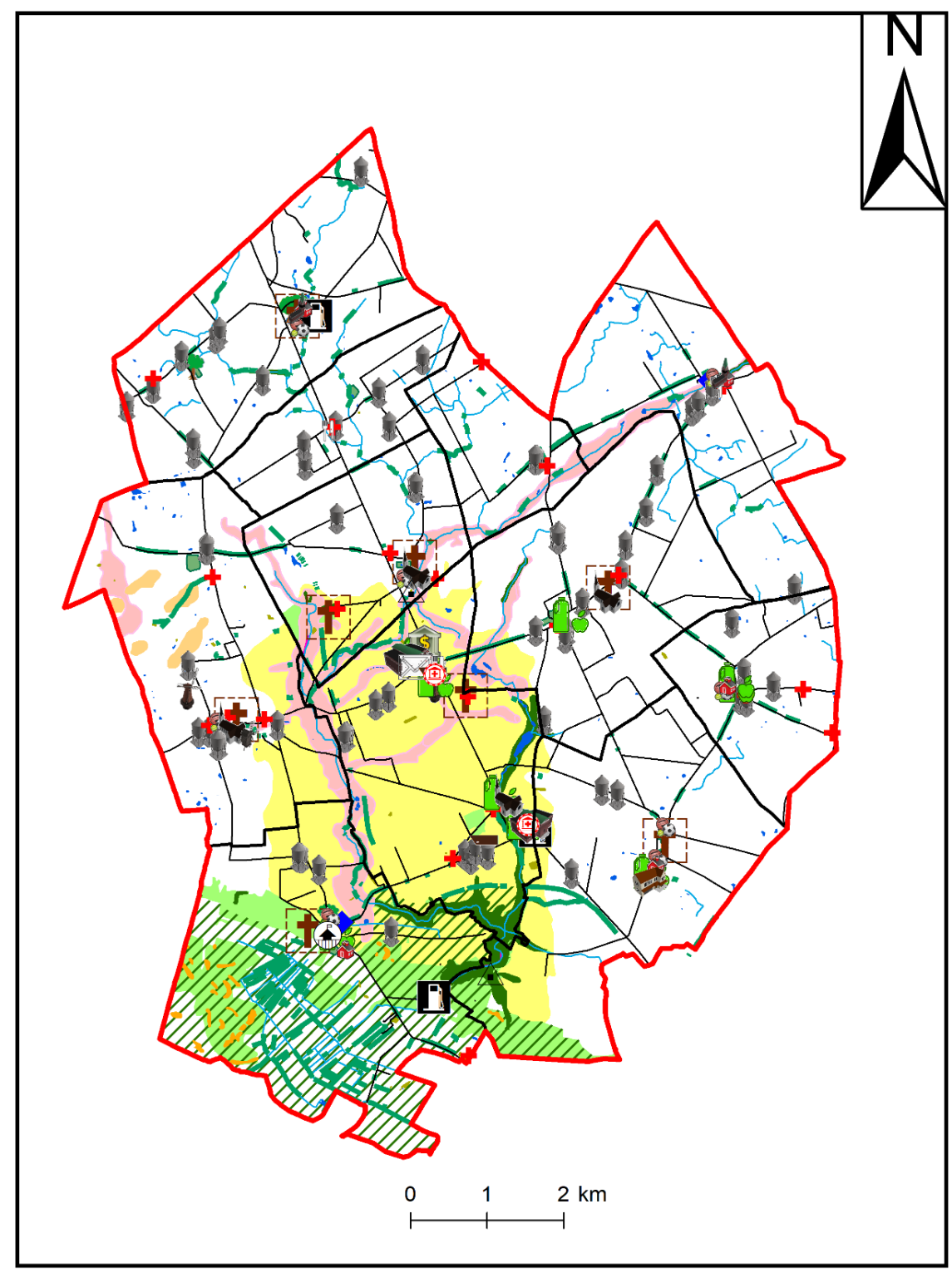

Ryc. 1. Mapa gminy Łubianka z wszystkimi cechami krajobrazowymi zinwentaryzowanymi podczas badań 


\section{Tutoring Gedanensis}

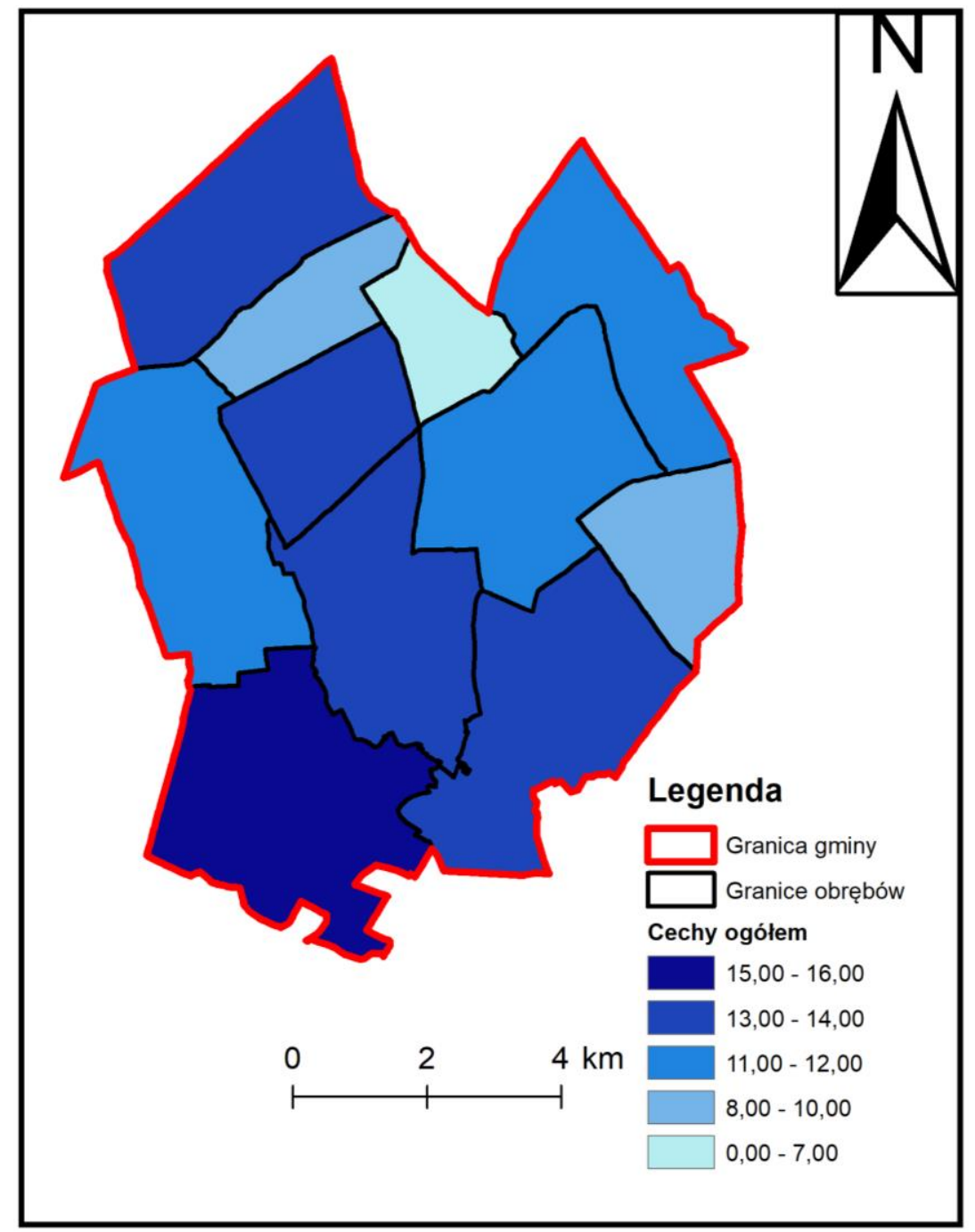

Ryc. 2. Kartogram na bazie mapy gminy Łubianka z analizą obrębów ewidencyjnych pod kątem ilości cech krajobrazowych

Ostatecznym efektem było natomiast wyznaczenie obrębu najbardziej bogatego w cechy krajobrazowe. Wyniki jakie uzyskałem na temat zróżnicowania cech krajobrazowych na terenie Łubianka dowodzą, że zalecane w Rozporządzeniu metody mogą mieć szerokie zastosowanie. W przypadku mojej pracy jako podkład merytoryczny wykorzystane zostały jedynie tabele ze wspomnianymi wyżej cechami krajobrazowymi, podczas gdy pełen audyt krajobrazowy jest jak już wiemy dużo bardziej skomplikowanym dokumentem. Potwierdzają to obecnie prowadzone prace w polskich województwach. Liczne ogłoszenia internetowe oraz apele poszczególnych władz wojewódzkich o pomoc oraz uwagi co do propozycji zawartych w audycie mogą świadczyć o dość zaawansowanym postępie w pracach. Ostatecznym terminem ukończenia aktualnie sporządzanych audytów jest w tych przypadkach zazwyczaj rok 2023, co tylko potwierdza potrzebę sprawnego zbadania struktury krajobrazów w danej jednostce administracyjnej. Dzięki temu można sprawnie podjąć działania na rzecz pogodzenia ochrony lokalnego środowiska z rozwojem przestrzennym w polskich miastach i wsiach. 


\section{Literatura:}

Ustawa z dnia 27 marca 2003 r. o planowaniu i zagospodarowaniu przestrzennym, Dz.U. 2003 nr 80 poz. 717.

Ustawa Krajobrazowa" z 2015 r. (Dz.U. 2015 poz. 774).

Rozporządzenie Rady Ministrów z dnia 11 stycznia 2019 r. w sprawie sporządzania audytów krajobrazowych, Dz.U. 2019 poz. 394.

\section{Źródła internetowe:}

[1] http://docplayer.pl/6675003-I-historiaochrony-przyrody.html (dostęp: 23.05.2021)

[2] https://www.irt.wroc.pl/strona-458-audyt_krajobrazowy.html (dostęp: 23.05.2021)
[3] https://www.teraz-srodowisko.pl/aktualnosci/audyty-krajobrazowe-czy-samorzady-dostana-wiecej-czasu-4213.html (dostęp: 23.05.2021)

https://www.gov.pl/web/gdos/geoserwis3 (dostęp: 23.05.2021)

Notka o Autorze: Jakub Wiśniewski jest studentem Geografii fizycznej z geoinformacją II stopnia na Uniwersytecie Gdańskim. W 2020 roku. ukończył studia inżynierskie na kierunku Gospodarka przestrzenna. W rozwoju akademickim i zawodowym skupia się przede wszystkim na poszerzaniu umiejętności z zakresu przetwarzania i wizualizacji danych przestrzennych. Jego główne zainteresowania to ochrona środowiska oraz teledetekcja. 